\title{
Antimicrobial Activity of Pulicaria Species from Turkey
}

\author{
Türkiye'deki Pulicaria Türlerinin Antimikrobiyal Aktivitesi
}

\author{
Ebru Özdemir Nath ${ }^{1,2}$ (D) Merve Bilgin ${ }^{3}$ (D), Bahar Gürdal ${ }^{4}$ (I) \\ 'Department of Pharmaceutical Botany, Faculty of Pharmacy, Altınbaș University, İstanbul, Turkey \\ ${ }^{2}$ Natural Products Research and Development Center (DÜAGEM), Altınbaş University, İstanbul, Turkey \\ ${ }^{3}$ Department of Pharmaceutical Microbiology, Faculty of Pharmacy, İstanbul Health and Technology University, Istanbul, Turkey \\ ${ }^{4}$ Department of Pharmaceutical Botany, Faculty of Pharmacy, İstanbul University, İstanbul, Turkey
}

ORCID ID: E.Ö.N. 0000-0002-0250-9084; M.B. 0000-0002-7734-8553; B.G. 0000-0003-4009-100X

Cite this article as: Ozdemir Nath E, Bilgin M, Gurdal B. Antimicrobial activity of pulicaria species from Turkey. Experimed 2021; 11(3): 195-9.

\begin{abstract}
Objective: In traditional medicine, the Pulicaria species are used for various disorders such as inflamed wounds, skin diseases, and bronchitis. This study investigated the antibacterial effect of five Pulicaria species in Turkey; (Pulicaria (P) arabica (L.) Cass., P. dysenterica (L.) Bernh., P. odora (L.) Reichb., P. sicula (L.) Moris, P. vulgaris (L.) Gaertn.) against certain significant pathogenic gram-negative and gram-positive reference bacteria.
\end{abstract}

Material and Method: Four extracts (decoction, infusion, aqueous, and ethanol (EtOH) extracts) were prepared from the Pulicaria species. The antimicrobial activity of the samples was examined against reference organisms; Bacillus (B) subtilis, Enterococcus faecalis, Escherichia coli, Klebsiella pneumoniae, Methicillin-resistant Staphylococcus (S) aureus (MRSA), Proteus mirabilis, S. aureus and Pseudomonas aeruginosa. The minimal bactericidal concentration (MBC) and minimum inhibitory concentration (MIC) ranges of the extract samples were demonstrated based on a microbroth dilution method.

Results: The EtOH extracts of the studied four Pulicaria species were found to be weakly active against gram-positive bacteria such as $B$. subtilis, MRSA and S. aureus but the EtOH extract of $P$. $d y-$ senterica showed exceptionally good activity against the reference strains of S. aureus, MRSA. No antimicrobial activity was detected in the infusion, decoction, and aqueous extracts.

Conclusion: The Pulicaria species, especially $P$. dysenterica could be evaluated as antimicrobial agents. Further studies with the extracts and essential oils from Pulicaria sp. on other bacteria and pathogenic fungi should be performed.

Keywords: Pulicaria, antimicrobial activity, extracts, Turkey

\section{ÖZ}

Amaç: Geleneksel tıpta Pulicaria türleri iltihaplı yaralar, cilt hastalıkları, bronşit gibi çeşitli rahatsızıklarda kullanılmaktadır. Bu çalışmada Türkiye'deki beş Pulicaria türünün (Pulicaria (P) arabica (L.) Cass., P. dysenterica (L.) Bernh., P. odora (L.) Reichb., P. sicula (L.) Moris, P. vulgaris (L.) Gaertn.), bazı önemli patojenik gram-negatif ve gram-pozitif referans bakterilere karşı etkisi araştırılmıştır.

Gereç ve Yöntem: Pulicaria türlerinden dört ekstre (kaynatma, infüzyon, sulu ve etanol (EtOH) ekstreleri) hazırlandı. Örneklerin, antimikrobiyal aktivitesi referans organizmalara karşı incelendi; Bacillus (B) subtilis, Enterococcus faecalis, Escherichia coli, Klebsiella pneumoniae, Metisiline dirençli Staphylococcus (S) aureus (MRSA), Proteus mirabilis, S. aureus ve Pseudomonas aeruginosa. Ekstre numunelerinin minimum bakterisidal konsantrasyon (MBC) ve minimum inhibitör konsantrasyon (MIC) aralıkları, mikrobroth seyreltme yöntemi temel alınarak gösterilmiştir.

Bulgular: İncelenen dört Pulicaria türünün EtOH ekstrelerinin; $B$. subtilis, MRSA ve $S$. aureus gibi gram pozitif bakterilere karşı genellikle zayıf aktif olduğu bulunmuştur, ancak $P$. dysenterica'nın EtOH ekstresi, S. aureus, MRSA referans suşlarına karşı çok iyi aktivite göstermiştir. İnüzyon, dekoksiyon ve sulu ekstrelerde antimikrobiyal aktivite tespit edilememiştir.

Sonuç: Pulicaria türleri, özellikle $P$. dysenterica antimikrobiyal ajan olarak değerlendirilebilir. Pulicaria sp.'den elde edilen ekstreler ve uçucu yağlar ile diğer bakteri ve bazı patojenik mantarlar üzerinde daha ileri çalışmalar yapılmalıdır.

Anahtar Kelimeler: Pulicaria, antimikrobiyal aktivite, ekstreler, Türkiye 


\section{INTRODUCTION}

The genus Pulicaria Gaertn. is represented with about 149 taxa in the world (1). The Pulicaria species are widely used in traditional Turkish medicine. For instance: the species are used for bronchitis, colds, and inflamed wounds in Turkey (2), for diabetes, ankle sprains, headaches, and flatulent colic in Yemen (3), as cicatrizant, anti-inflammatory, for muscular-skeletal diseases, and skin diseases in Spain $(4,5)$, and for abdominal pain in Mauritania (6). These species are also used in folk veterinary medicine in Italy as antiparasitics, repellents, and for respiratory ailments (7).

Distinct types of Pulicaria phytochemicals have been reported, including essential oils, flavonoids, phenolic derivatives, monoterpene derivatives, sesquiterpenes, diterpenes, triterpenes, steroids, and others (8). Mohamed et al. (2020) demonstrated that methanolic crude extracts of Pulicaria $(P)$ undulata and $P$. crispa were rich in coumarins, saponins, sterols, tannins, and terpenes based on preliminary phytochemical screening (9). Until that time no flavonoids, alkaloids, and anthraquinones were found. According to identification of the essential oils of P. crispa; 1.4-ditert-butylbenzene, carvone, caryophyllene, and neryl (s)- 2-methylbutanoate were determined as the main compounds. The percentages of active ingredients are given respectively; $22.81 \%, 11.80 \%, 13.19 \%$, and $10.33 \%$. In the same study the main compounds of $P$. undulata essential oil were determined as camphor, thymyl acetate, bicycle, and azulenol. The percentages of active ingredients are given respectively $44.48 \%, 10.31 \%, 3.46 \%$, and $3.40 \%$. In the literature, there are several studies on essential oil constituents of Pulicaria species (10-16).

In the literature, there are several biological activity studies on Pulicaria species such as antimicrobial, antioxidant, anticholinesterase, analgesic, antipyretic, anti-inflammatory, cytotoxicity (HL-60, MCF-7, Hep-G2 cells), and hepatoprotective $(11,14,17-$ 22). The number of studies on the antimicrobial activities of the medicinal plant as a potential antimicrobial drug which functions as new antibacterial agents have increased in recent years (23). The antimicrobial activity of essential oils, plant extracts or isolated compounds used in traditional medicines is the subject of several studies. This study was conducted with the idea of determining the antimicrobial activities of Pulicaria species to illuminate the traditional uses of wound healing, bronchitis, colds, skin diseases, and abdominal pain.

The main goals of this research were to find out how effective five Pulicaria species (P. arabica (L.) Cass., P. dysenterica (L.) Bernh., P. odora (L.) Reichb., P. sicula (L.) Moris, P. vulgaris (L.) Gaertn.) were at fighting bacteria. Aqueous extracts, ethanol (EtOH) extracts, infusion, and decoction of these five Pulicaria species were evaluated against the reference strains of forementioned microorganisms.

\section{MATERIAL AND METHOD}

\section{Plant Materials}

Pulicaria species were gathered between 2018-2019. The studied species, herbarium numbers, and localities are given in Table 1. The plants were identified by Dr. Bahar Gürdal and Dr. Ebru Özdemir Nath. The Pulicaria species are stored in Istanbul University Herbarium of the Faculty of Pharmacy (ISTE).

\section{Extraction of Plant Materials}

For each species, four extracts (infusion, decoction, aqueous, and $\mathrm{EtOH}$ extracts) were prepared from aerial parts. The diverse techniques of extract preparation were chosen to compare the biological activity of traditionally made decoctions and infusions to water and $\mathrm{EtOH}$ extracts prepared under controlled laboratory circumstances. At room temperature, the plant materials were air-dried and powdered. For EtOH extracts, 50 grams $(\mathrm{g})$ of each species were macerated with EtOH $(250 \mathrm{~mL}$, Merck) for 24 hours at room temperature and filtered. The solvents were evaporated to dryness under vacuum (Buchi Rotavapor R-210). For aqueous extracts, $5 \mathrm{~g}$ of each species were macerated with distilled water $(25 \mathrm{~mL})$ for 24 hours. Then it was filtered. Infusions were prepared by adding $25 \mathrm{~mL}$ of boiling distilled water to each species $(5 \mathrm{~g})$ and allowed to stand at room temperature for $20 \mathrm{~min}$. For decoction, $5 \mathrm{~g}$ of each species were added to $25 \mathrm{~mL}$ of distilled water and heated for 20 minutes, and then filtered.

\section{Determination of Antimicrobial Activity}

The antibacterial effect of the plant extracts was evaluated against some of the reference bacteria using a standard microbroth dilution technique as defined in the guideline of Clinical Laboratory Standards Institute (24). The test organisms were provided from the Microorganism Culture Collection of Istan-

Table 1. Studied species information.

\begin{tabular}{lll}
\hline Species & Locality & Herbarium number \\
\hline P. arabica & Muğla: Bodrum, Göltürkbükü, 19.vii.2019, B. Gürdal, E. Özdemir Nath & ISTE 116891 \\
\hline P. dysenterica & İstanbul: Çatalca, Subaşı, 14.viii.2018, B. Gürdal, E. Özdemir Nath & ISTE 116730 \\
\hline P. odora & Yalova: Armutlu, 06.vi.2019, B. Gürdal, E. Abamor & ISTE 116747 \\
\hline P. sicula & Bursa: Nilüfer, Gölyazı, 19.x.2019, B. Gürdal, E. Özdemir Nath & ISTE 116910 \\
\hline P. vulgaris & Edirne: Enez, Sultaniçe, 20.viii.2019, B. Gürdal, E. Özdemir Nath & ISTE 116895 \\
\hline
\end{tabular}


bul University, Department of Pharmaceutical Microbiology. The reference antimicrobials, Ciprofloxacin (Bayer Türk Kimya San. Istanbul/Turkey) as antibiotic and dimethyl sulfoxide (Merck, Darmstadt, Germany) as a solvent and growth mediums Mueller Hinton Broth (MHB) and tryptic soy agar (TSA) were obtained from BD Difco (Fisher Scientific, Göteborg, Sweden).

DMSO was used as a solvent for EtOH extracts with a concentration of $10,000 \mu \mathrm{g} / \mathrm{mL}$ and as a vehicle control to detect the possible inhibitory activity of the extract dilution. Ciprofloxacin was used as a reference antibiotic. The minimum inhibitory concentration (MIC) and minimal bactericidal concentrations $(\mathrm{MBC})$ were determined for each extract.

\section{Examination of MIC and MBC Assays}

Inoculums were prepared from overnight cultures from each microorganism in MHB medium. The density was adjusted using McFarland densitometer (Biosan, Riga, Latvia) equivalent to $0.5 \mathrm{McF}$ arland and diluted $1 / 100$ to the final concentration $10^{6}$ $\mathrm{CFU} / \mathrm{m}$.

After the preparation of inoculums, the microtiter plate wells were inoculated with $50 \mu \mathrm{g} / \mathrm{mL} \mathrm{MHB}$ starting from the second until the last well. 10,000 $\mu \mathrm{g} / \mathrm{mL}$ from EtOH extracts and $100,000 \mu \mathrm{g} / \mathrm{mL}$ concentration from infusion, decoction, and maceration extracts were inoculated to the first two wells. Two-fold serial dilutions were made (starting concentration of $10,000 \mu \mathrm{g} / \mathrm{m} \mathrm{L}$ and $100,000 \mu \mathrm{g} / \mathrm{mL}$ in the first well to the minimum concentration $19.52 \mu \mathrm{g} / \mathrm{mL}$ and $195.2 \mu \mathrm{g} / \mathrm{mL}$ in the tenth well respectively). Finally, bacterial suspensions and $25 \mu \mathrm{l}$ of resazurin solution $(0.001 \%)$ were inoculated to each well, except the negative control well, and the range of $5000-9.76 \mu \mathrm{g} / \mathrm{mL}$ and $50.000-97.6 \mu \mathrm{g} / \mathrm{mL}$ were achieved, respectively.

The standard antibiotic ciprofloxacin's 2-fold serial dilutions were prepared in cation-adjusted $\mathrm{MHB}(\mathrm{CAMHB})$, in the ranges 5,120 to $64 \mathrm{mg} / \mathrm{L}$. $50 \mu \mathrm{L}$ from 32 to $0.03 \mu \mathrm{g} / \mathrm{mL}$ concentrations of the antibiotic solution as well as DMSO were directly inoculated to each corresponding microtiter well by serial dilutions and the microtiter plates were incubated at $37^{\circ} \mathrm{C}$ for 24 hours. Microbial growth in the wells was determined as positive which turned from lilac to pink by resazurin dye. The MIC was defined as the lowest concentration of the samples that completely inhibits the growth of microorganisms. To determine the MBC, broth samples were removed from the wells with no growth and placed on the TSA plates overnight at $37^{\circ} \mathrm{C}$. MBCs were detected with samples that did not show any bacterial growth.

\section{RESULTS}

The EtOH extract of $P$. sicula showed activity against EnterococCus (E) faecalis, Methicillin-resistant Staphylococcus (S) aureus (MRSA), and S. aureus and the EtOH extracts of P. arabica, P. vulgaris and $P$. odora showed almost the same activity against $S$. aureus, MRSA, and $E$. faecalis. The EtOH extract of $P$. odora was also active against Bacillus (B) subtilis. Especially the EtOH extract of $P$. dysenterica was found active against most of the reference organisms. The MIC/ MBC results of the EtOH extract of P. dysenterica against MRSA, S. aureus, E. faecalis, Proteus mirabilis and Klebsiella (K) pneumoniae are $39 / 156 \mu \mathrm{g} / \mathrm{mL}, 156 \mu \mathrm{g} / \mathrm{mL}$, $1250 \mu \mathrm{g} / \mathrm{mL}, 625 / 1250 \mu \mathrm{g} / \mathrm{mL}$, and $625 / 1250 \mu \mathrm{g} / \mathrm{mL}$, respectively as shown in Table 2.

The findings show that the EtOH extracts of Pulicaria species in Turkey are especially active against gram-positive pathogens such as MRSA, S. aureus and E. faecalis with a decrease up to 2-64 times in MIC values compared to DMSO, as shown in Table 2. In each case, the activities of the EtOH extracts of Pulicaria species were lower than those of the standard antibiotic ciprofloxacin. No antimicrobial activity was detected in the infusion, decoction, and aqueous extracts. It has been also determined that the Pulicaria extracts have not shown any antibacterial activity against some of the clinically important pathogenic bacteria such as Pseudomonas aeruginosa and Escherichia (E) coli.

Table 2. The results of antimicrobial assays (Pulicaria EtOH extracts, $M I C s / M B C s, \mu g / m L$ ).

\begin{tabular}{lcccccccc}
\hline Pulicaria sp. & E. coli & S. aureus & MRSA & E. faecalis & K. pneumoniae & B. subtilis & $\begin{array}{c}\text { Pseudomonas } \\
\text { aeruginosa }\end{array}$ & $\begin{array}{c}\text { Proteus } \\
\text { mirabilis }\end{array}$ \\
\hline P. sicula & 1250 & 625 & 312.5 & 2500 & 1250 & 1250 & 1250 & 1250 \\
\hline P. arabica & 1250 & $625 / 1250$ & 625 & $1250 / 2500$ & 1250 & 1250 & 1250 & 1250 \\
\hline P. vulgaris & 1250 & 1250 & 625 & $1250 / 2500$ & 1250 & 1250 & 1250 & 1250 \\
\hline P. odora & 1250 & $625 / 1250$ & 625 & $1250 / 2500$ & 1250 & $625 / 1250$ & 1250 & 1250 \\
\hline P. dysenterica & 1250 & 156 & $39 / 156$ & $1250 / 1250$ & $625 / 1250$ & 1250 & 1250 & 1250 \\
\hline DMSO & 1250 & 2500 & 2500 & 2500 & 0.5 & 0.5 & 0.5 & 2500 \\
\hline Ciprofloxacin & 0.125 & 1 & 0.5 & 0.5 & 0.5 &
\end{tabular}

Reference strains: Staphylococcus aureus ATCC 25923, Escherichia coli ATCC 25922, MRSA (methicillin-resistant S. aureus) ATCC 43300, Enterococcus faecalis ATCC 29212, Klebsiella pneumoniae ATCC 4352, Proteus mirabilis ATCC 14153, Pseudomonas aeruginosa ATCC 27853, Bacillus subtilis ATCC 6633 


\section{DISCUSSION}

In the studies conducted to ascertain the antimicrobial activities of the Pulicaria species, successful results on gram-positive and gram-negative, clinically important bacteria were obtained in different extracts. Nickavar and Mojab, (25) assessed the methanolic, aqueous, and chloroform extracts of $P$. dysenterica aerial parts from Tehran, Iran for their antibacterial effect using the disc-diffusion technique. The six bacteria - E. coli, Bacillus cereus, Shigella dysenteriae, Salmonella typhi, Vibrio cholera and $S$. aureus - were tested and the most powerful extract against V. cholera, B. cereus, S. aureus and was the methanolic extract. All the extracts against Vibrio cholera were successfully active. Similar to this study, the EtOH extract of $P$. dysenterica has good activity against tested gram-positive bacteria. In both studies, there were not any activity against one of the significant pathogenic gram-negative bacteria such as $E$. coli.

Touati et al. (26), researched the antibacterial activity of leaves and roots of $P$. odora from northern Algeria. The findings showed that $S$. aureus was the most sensitive to the acetonic root extract, while Pseudomonas aeruginosa was the most resistant to the chloroformic leaf extract. According to Naqvi et al. (27), the findings of the analysis revealed that EtOH extract of $P$. gnaphalode from Quetta, Pakistan demonstrated a maximum inhibition zone for $B$. subtilis from all others. The methanol extract (ME) demonstrated a maximum inhibition zone for S. aureus. Zhanzhaxina et al. (28), analyzed the structure of the EtOH and $\mathrm{CHCl}_{3}$ extracts of $P$. vulgaris from Akmola, Kazakhstan, and determined the biological function of the extracted compounds. All isolated compounds have been tested against E. coli, S. aureus, B. cereus, Salmonella enteritidis, and Candida albicans. The percent inhibition showed negative values in some cases, indicating that the compound did not decrease the number of bacteria. The antimicrobial activity of the $\mathrm{CH}$ ${ }_{2} \mathrm{Cl}_{2}, \mathrm{MeOH}$, EtOAc extracts of the $P$. undulata aerial parts from Egypt was investigated by Abdel Bar et al. (29). The antimicrobial activity was measured against $S$. aureus, K. pneumoniae, $E$. coli, and Pseudomonas aeruginosa, and C. albicans. The phenolic rather than the terpenoidal compounds exhibited remarkable antimicrobial activity. The research of Foudah et al. (30), was intended to question the antimicrobial activity of the ME of $P$. crispa from Alkharj- the, Saudi Arabia. The antimicrobial activity was tested against S.aureus, B. subtilis, E. coli, K. pneumonaie, Aspergillus niger, Proteus vulgaris, and C. albicans. Antimicrobial activities were observed which may be due to the presence of phenols, tannins, and flavonoids in the ME. The study of El-Shahaby et al. (31) aimed to determine the antimicrobial potential of ethyl acetate and diethyl ether extracts of $P$. incisa (Lam.) DC from Egypt. The antimicrobial activities of extracts against K. pneumoniae, B. subtilis, S. epidermidis, $S$. aureus, E. coli, and C. albicans were determined by the disc diffusion technique. As a result of this study, the ethyl acetate extract has antimicrobial effect on S. epidermidis, S. aureus and $C$. albicans while the diethyl ether has activity against $B$. subtillis and C. albicans. Nair et al. (32) screened for antibacterial activity of $P$. wightiana from Rajkot Gujarat, India. Agar disc diffusion assay was used for aqueous extract and Agar disc diffusion assay used for ME against Staphylococcus epidermidis, Pseudomonas testosteroni, B. subtilis, Proteus morganii, Micrococcus flavus, and $K$. pneumoniae. The ME showed greater activity than the aqueous extract. The methanolic extracts are active against Micrococcus flavus, B. subtilis and Proteus morganii. The aqueous extract revealed a negligible amount of action. In this study, the aqueous extracts of studied Pulicaria species also showed the same results.

\section{CONCLUSION}

In this research, the antimicrobial activity of five species of $\mathrm{Pu}$ licaria in Turkey was investigated by the microdilution method modified with resazurin. The EtOH extracts obtained from Pulicaria species were found to be weakly active against the gram-positive bacteria such as B. subtilis, MRSA, S. aureus, but the EtOH extract of $P$. dysenterica showed particularly good activity against $S$. aureus, MRSA. These results suggest that the EtOH extract of $P$. dysenterica would be a good therapeutic agent against these bacteria. Further studies such as in vitro antimicrobial activity testing are suggested to evaluate antifungal and antibacterial activities of essential oils obtained from active Pulicaria species in Turkey.

Acknowledgement: The authors thank Scientific Research Projects Coordination Unit of Istanbul University and Altınbaş University Natural Products Research and Development Center (DÜAGEM).

Ethics Committee Approval: Ethics committee approval is not required because of no material or experimental animal that would require permission.

Author Contributions: Conception/Design of Study - E.Ö.N., M.B., B.G.; Materials - E.Ö.N., M.B., B.G.; Data Collection - E.Ö.N., M.B., B.G.; Analysis and/or Interpretation - E.Ö.N., M.B., B.G.; Drafting Manuscript - E.Ö.N., M.B., B.G.; Final Approval and Accountability - E.Ö.N., M.B., B.G.

Conflict of Interest: The authors have no conflict of interest to declare.

Financial Disclosure: This study was funded by Istanbul University Scientific Research Project Unit. Project number: 29555.

Teşekkür: Yazarlar, İstanbul Üniversitesi Bilimsel Araştırma Projeleri Koordinasyon Birimi'ne ve Altınbaş Üniversitesi Doğal Ürünler Araştırma ve Geliştirme Merkezi (DÜAGEM)'e teşekkür eder.

Etik Komite Onayı: Bu çalışmada, etik komite iznine gerek duyulacak bir materyal ya da deney hayvanı kullanılmamıştır.

Yazar Katkıları: Çalışma Konsepti/Tasarımı - E.Ö.N., M.B., B.G.; Materyal: E.Ö.N., M.B., B.G.; Veri Toplama - E.Ö.N., M.B., B.G.; Veri Analizi/Yorumlama - E.Ö.N., M.B., B.G.; Yazma - E.Ö.N., M.B., B.G.; Son Onay ve Sorumluluk - E.Ö.N., M.B., B.G.

Çıkar Çatışması: Yazarlar çıkar çatışması bildirmemişlerdir.

Finansal Destek: Bu çalışma, İstanbul Üniversitesi Bilimsel Araştırma Proje Birimi tarafından finanse edilmiştir. Proje numarası: 29555. 


\section{REFERENCES}

1. The Plant List. 2010; Version 1. Available from: URL: http://www. theplantlist.org/

2. Tuzlacı E. Türkiye Bitkileri Geleneksel İlaç Rehberi. İstanbul: İstanbul Tıp Kitabevleri; 2016.

3. Al-Fatimi M. Ethnobotanical survey of medicinal plants in central Abyan governorate, Yemen. J Ethnopharmacol 2019; 241: 111973. [CrossRef]

4. Gonzalez-Tejero MR, Casares-Porcel M, Sanchez-Rojas CP, Ramiro-Gutierrez JM, Molero-Mesa J, Pieroni A, et al. Medicinal plants in the Mediterranean area: Synthesis of the results of the project Rubia. J Ethnopharmacol 2008; 116: 341-57. [CrossRef]

5. Vazquez FM, Suarez MA, Perez A. Medicinal plants used in the Barros Area, Badajoz Province (Spain). J Ethnopharmacol 1997; 55: 81-5. [CrossRef]

6. Yebouk C, Redouan FZ, Benítez G, Bouhbal M, Kadiri M, Boumediana Al, et al. Ethnobotanical study of medicinal plants in the Adrar Province, Mauritania. J Ethnopharmacol 2020; 246: 112217. [CrossRef]

7. Viegi L, Pieroni A, Guarrera PM, Vangelisti R. A review of plants used in folk veterinary medicine in Italy as basis for a databank. J Ethnopharmacol 2003; 89: 221-44. [CrossRef]

8. Liu L, Yang J, Shi Y. Phytochemicals and biological activities of Pulicaria species. Chem Biodivers 2010; 7(2): 327-49. [CrossRef]

9. Mohamed EAA, Muddathir AM, Osman MA. Antimicrobial activity, phytochemical screening of crude extracts, and essential oils constituents of two Pulicaria spp. growing in Sudan. Sci Rep 2020; 10(1): 1-8. [CrossRef]

10. Hanbali FE, Akssira M, Ezoubeiri A, Mellouki F, Benherraf A, Blazquez AM, et al. Chemical composition and antibacterial activity of essential oil of Pulicaria odora L. J Ethnopharmacol 2005; 99(3): 399-401. [CrossRef]

11. Ali NAA, Sharopov FS, Alhaj M, Hill GM, Porzel A, Arnold N, et al. Chemical composition and biological activity of essential oil from Pulicaria undulata from Yemen. Nat Prod Commun 2012; 7(2): 25760. [CrossRef]

12. Fawzy GA, Al Ati HY, El Gamal AA. Chemical composition and biological evaluation of essential oils of Pulicaria jaubertii. Pharmacogn Mag 2013; 9(33): 28-32. [CrossRef]

13. Asghari G, Zahabi F, Eskandarian A, Yousefi H, Asghari M. Chemical composition and leishmanicidal activity of Pulicaria gnaphalodes essential oil. Res J Pharmacogn 2014; 1(4): 27-33.

14. Sharifi-Rad J, Miri A, Hoseini-Alfatemi SM, Sharifi-Rad M, Setzer WN, Hadjiakhoondi A. Chemical composition and biological activity of Pulicaria vulgaris essential oil from Iran. Nat Prod Commun 2014; 9(11): 1633-6. [CrossRef]

15. Chaib F, Allali H, Bennaceur M, Flamini G. Chemical composition and antimicrobial activity of essential oils from the aerial parts of Asteriscus graveolens (Forssk.) Less. and Pulicaria incisa (Lam.) DC.: Two Asteraceae herbs growing wild in the Hoggar. Chem Biodivers 2017; 14(8): e1700092. [CrossRef]

16. Zardi-Bergaoui A, Jelassi A, Daami-Remadi M, Harzallah-Skhiri F, Flamini G, Ascrizzi R, et al. Chemical composition and bioactivities of essential oils from Pulicaria vulgaris subsp. dentata (Sm.) Batt. growing in Tunisia. J Essent Oil Res 2020; 32(2): 111-20. [CrossRef]
17. Triana J, López M, Pérez FJ, González-Platas J, Quintana J, Estévez $\mathrm{F}$, et al. Sesquiterpenoids from Pulicaria canariensis and their cytotoxic activities. J Nat Prod 2005; 68(4): 523-31. [CrossRef]

18. Yusufoglu HS. Analgesic, antipyretic, anti-inflammatory, hepatoprotective and nephritic effects of the aerial parts of Pulicaria arabica (Family: Compositae) on rats. Asian Pac J Trop Med 2014; 7: S583-S590. [CrossRef]

19. Hussien TA, El-Toumy S, Hassan H, Hetta M. Cytotoxic and antioxidant activities of secondary metabolites from Pulicaria undulata. Int J Pharm Pharm Sci 2016; 8(9): 150-5. [CrossRef]

20. Ravandeh M, Valizadeh J, Noroozifar M, Khorasani-Motlagh M. Screening of chemical composition of essential oil, mineral elements and antioxidant activity in Pulicaria undulata (L.) CA Mey from Iran. J Med Plant Res 2011; 5(10): 2035-40.

21. El-Kamali HH, Mahjoub SAT. Antibacterial activity of Francoeuria crispa, Pulicaria undulata, Ziziphus spina-christi and Cucurbita pepo against seven standard pathogenic bacteria. Ethnobot Leafl 2009; 13: 722-33.

22. Ali NAA, Crouch RA, Al-Fatimi MA, Arnold N, Teichert A, Setzer $W N$, et al. Chemical composition, antimicrobial, antiradical and anticholinesterase activity of the essential oil of Pulicaria stephanocarpa from Soqotra. Nat Prod Commun 2012; 7(1): 1136. [CrossRef]

23. Rios JL, Recio MC. Medicinal plants and antimicrobial activity. J Ethnopharmacol 2005; 100(1-2): 80-4. [CrossRef]

24. Clinical and Laboratory Standards Institute (CLSI), Performance Standards for Antimicrobial Susceptibility Testing: Approved Standard M100-S22. Wayne, Pennsylvania, 2012.

25. Nickavar B, Mojab F. Antibacterial activity of Pulicaria dysenterica extracts. Fitoterapia 2003; 74(4): 390-3. [CrossRef]

26. Touati N, Saidani K, Boudries H, Hammiche H, Ouazene N, Bedjou F. Antibacterial activity of phenolic compounds of Pulicaria odora, wild plant in northern Algeria. Int Food Res J 2018; 25(5): 2021-30.

27. Naqvi SAR, Shah SMA, Kanwal L, Saeed M, Atta-ul-Haq, Nisar J, et al. Antimicrobial and antihypercholesterolemic activities of Pulicaria gnaphalodes. Dose-Response 2020; DOI: 10.1177/1559325820904858. [CrossRef]

28. Zhanzhaxina AS, Seiilgazy M, Jalmakhanbetova RI, Ishmuratova MY, Seilkhanov TM, Oyama M, et al. Flavonoids from Pulicaria vulgaris and their antimicrobial activity. Chem Nat Compd 2020; 56(5): 915-7. [CrossRef]

29. Abdel Bar FM, Elsbaey M, Taha N, Elgaml A, Abdel-Fattah GM. Phytochemical, antimicrobial and antiquorum-sensing studies of Pulicaria undulata L.: A revision on the structure of $1 \beta, 2 \alpha, 3 \beta, 19 a$, 23-pentahydroxy-urs-12-en-28-oic acid. Nat Prod Res 2020; 34(6): 804-9. [CrossRef]

30. Foudah Al, Alam A, Soliman GA, Salkini MA, Ahmed El, Yusufoglu HS. Pharmacognostical, antioxidant and antimicrobial studies of aerial part of Pulicaria crispa (Family: Asteraceae). Bull Environ Pharmacol Life Sci 2015; 4(12): 19-27. [CrossRef]

31. El-Shahaby O, El-Zayat M, Rabei R, Aldesuquy HS. Phytochemical constituents, antioxidant activity and antimicrobial potential of Pulicaria incisa (lam.) DC as a folk medicinal plant. Prog Chem Biochem Res 2019; 2(4): 222-7. [CrossRef]

32. Nair R, Kalariya T, Chanda S. Antibacterial activity of some selected Indian medicinal flora. Turk J Biol 2005; 29(1): 41-7. 